\title{
The combined use of triacylglycerols containing medium-chain fatty acids and exogenous lipolytic enzymes as an alternative to in-feed antibiotics in piglets: concept, possibilities and limitations. An overview
}

\author{
J. A. Decuypere and N. A. Dierick* \\ Department of Animal Production, Faculty of Agricultural and Applied Biological Sciences, Ghent University, \\ Proefhoevestraat 10, B-9090 MELLE, Belgium
}

\begin{abstract}
In the search for alternatives to banned in-feed antibiotics, a concept was developed based on studies with medium-chain fatty acid-containing triacylglycerols (MCTAG) and selected lipases for in situ generation of diacylglycerols, monoacylglycerols and medium-chain fatty acids (MCFA) in the stomach and proximal gut of piglets. MCFA are known to have strong antibacterial properties but can hardly be used as such because of their repellent odour and taste. Those problems could be overcome by the generation of MCFA in situ. The concept was tested in vitro and validated in vivo with gastric-cannulated piglets and under field conditions, including effects on zootechnical performance, with classical antibacterial growth promoters or organic acids acting as positive controls. Furthermore, the metabolic and dietary constraints on the nutritional and nutritive use of MCTAG and/or MCFA (for example, the effects on digestive physiology, gut flora, feed intake, performance, carcass composition) are reviewed. The role of natural preduodenal lipase activity, the presence of endogenous plant lipase activity in raw materials and the feasibility for exogenous lipase addition to the feed are discussed, in order to optimize the concept. The present review illustrates the similarity of the action of MCFA and commonly used antimicrobials on the flora (total flora, Gram-positive flora, Gram-negative flora, potential pathogens) and epithelial morphology and histology in the foregut. These observations are believed to be the basis for obtaining optimal growth performances. In addition, these naturally occurring antimicrobial agents have little or no human or animal toxicity and induce no problems of residues and cross-resistance induction. They are proposed as a valuable alternative to in-feed antibiotics, used for growth promotion, and even for the preventive and curative treatment of gastrointestinal diseases.
\end{abstract}

Animal feeds: Antimicrobials: Gut flora: Medium-chain fatty acids: Lipase

\section{Introduction}

As a general ban of all in-feed antibiotics in the European Union is foreseen for 2005, animal nutritionists are highly interested in active alternatives. Because there is a general consensus that the growth-promoting effect is mediated through the antibiotics' regulating influence on the gut flora and altering directly or indirectly epithelial functions in the small intestine (Thomke \& Elwinger, 1998b; Anderson et al. 1999), a number of alternatives with comparable effects have been proposed, although a clear-cut validation is lacking for most of them. These are: enzymes, probiotics and prebiotics, certain non-digestible oligosaccharides, fermented liquid feeds, blood plasma proteins, $\mathrm{Zn}$, dietary acidifiers, herbs and plant extracts, antimicrobial peptides and lytic phages (Roth \& Kirchgessner, 1998; Thomke \& Elwinger, 1998c; Cowan, 1999; Verstegen \& Schaafsma, 1999; Jensen et al. 2003; Joerger, 2003; Lis-Balchin, 2003; Mroz, 2003). However, at present, none of these compounds can completely replace antibiotics in the diet of piglets. Non-nutritional strategies (weaning age, management, environmental control, genetics), although very important, are not considered in the present review.

The most promising compounds for the feeding of weaner piglets, growers and finishers, seem to be the

\footnotetext{
Abbreviations: IEL, intra-epithelial lymphocytes; LCTAG, long-chain fatty acid-containing triacylglycerols; MCFA, medium-chain fatty acids; MCTAG; medium-chain fatty acid-containing triacylglycerols; NEFA, non-esterified fatty acids; SCFA, short-chain fatty acids; TAG, triacylglycerols.

* Corresponding author: Dr N. A. Dierick, fax +32 926490 99, email Noel.Dierick@UGent.be
} 
organic short-chain fatty acids (SCFA); formic, acetic, propionic and butyric acids, commonly known as volatile fatty acids; and lactic, sorbic, fumaric, malic, tartaric and citric acids (Partanen \& Mroz, 1999). However the health and performance effects of these organic acids are not always consistent (Jensen, 1998). The considerable variation in the efficacy of different organic acids seems to be related to differences in dietary composition and the physico-chemical characteristics of the ingredients (for example, acidbinding capacity), animals (for example, age) and type and level of acid(s) or their salts.

\section{Background of the concept}

In most mammals the alimentary tract becomes heavily populated with bacteria within a few hours after birth. Afterwards, a stabilized population persists throughout life, greatly depending on the relationship of age with diet. Baby rabbits are exceptional in this respect, because during the sucking period their stomach and small intestine are virtually sterile.

Further studies revealed that the fat present in rabbit milk was transformed into antimicrobial substances by lipolytic enzymes present in the stomach wall of the sucking rabbit (Canas-Rodriguez \& Smith, 1966; Smith, 1966). Indeed, antimicrobial activity was not found in the rabbit milk itself and neither triacylglycerols (TAG) nor diacylglycerols inactivate microbes (Isaacs, 2001).

SCFA and medium-chain fatty acids (MCFA) are fatty acids made up of 1-5 and 6-12 C atoms, respectively. The antimicrobial activity of SCFA and MCFA or their derivatives (for example, monoacylglycerols) has been known for a long time and is summarized in the work of Kabara et al. (1972). They were further classified as food-grade germicidal agents, pharmaceutical preservatives, silage additives or feed preservatives. Meeus (1994) and Decuypere \& Meeus (1995) tested the antimicrobial activity of MCFA in vitro against the components of the small-intestinal microflora of weanling piglets. They suggested that, in combination with a proper lipase, MCFA could be an interesting alternative to antibiotic growth promoters. By substituting part of the tallow in the milk replacer with tricaproin or tricaprylin, the growth of preruminant calves was increased by $40 \%$ (Aurousseau et al. 1984). The authors explained this phenomenon by the high antimicrobial efficacy of MCFA released by the enzymes in the gut lumen and by their fuelling action for the enterocytes. In the stomach contents of babies, inhibitory fatty acids or their derivatives could be generated by endogenous lipases, as noted by Hamosh et al. (1981, 1989), Isaacs et al. $(1990,1992,1995)$ and Hamosh (1997).

\section{Occurrence of medium-chain fatty acid-containing triacylglycerols in man and animals}

The occurrence of medium-chain fatty acid-containing TAG (MCTAG) in the milk of women and different animals is variable and the causes of this are not well understood. There is some evidence that their presence and concentration are related to the level of immaturity of the young at birth (Smith, 1980). A more in-depth literature

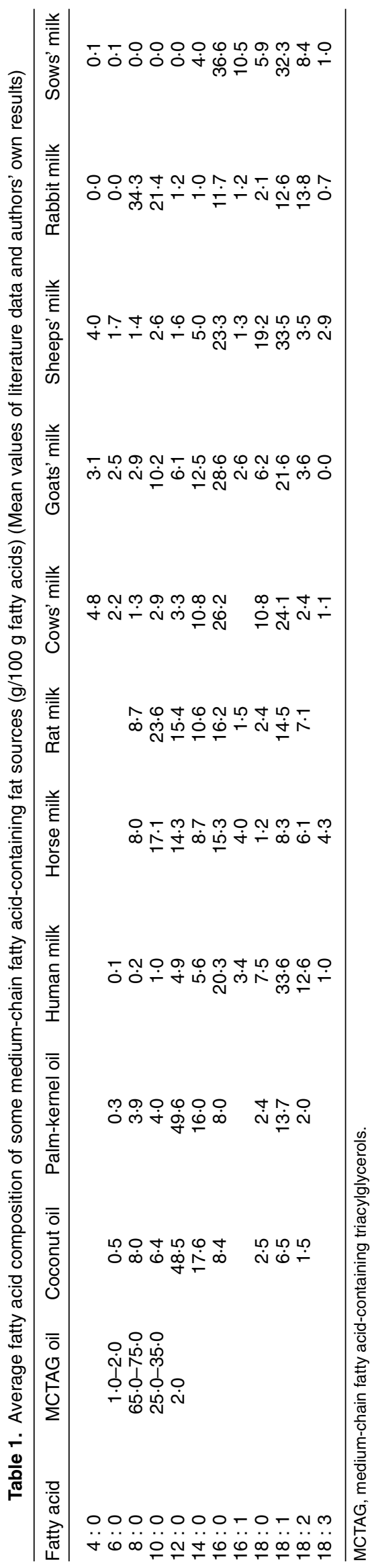


Table 2. Presence and anatomical site of mammalian and poultry preduodenal lipase activities* (mainly after Moreau et al. 1988)

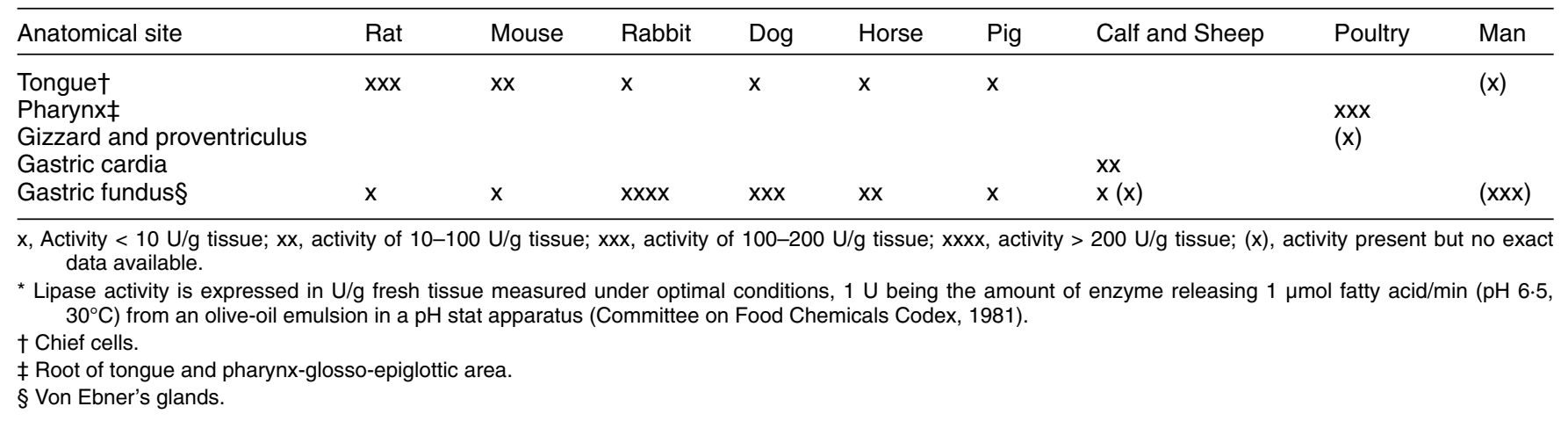

search supports the relatively important contribution of MCFA in the milk-lipid of certain mammals including the rabbit, goat, mare, rat, mouse and elephant, while in other species (cow, sheep, man) the concentrations are rather low or even negligible; for example, in the milk of the sow, camel or guinea-pig (Table 1).

\section{Occurrence of preduodenal lipases in man and animals}

In man and most mammals there is a more or less developed preduodenal lipase. The origin is different; lingual and/or pharyngeal or gastric, and for both the term preduodenal lipases (to differentiate from pancreatic lipases) is used. Common properties of the preduodenal lipases are that they are active over a broad and rather acid $\mathrm{pH}$ range (except in the pig) (Höller, 1970; Newport \& Howarth, 1985; Moreau et al. 1988). These preduodenal lipases have a strong preference for MCFA in milk fat. High activities are found in human subjects, preruminant calves, young rabbits and dogs, while activities are moderate in piglets and low in carnivorous birds. In poultry and other birds they are absent (Table 2).

\section{Natural sources of medium-chain fatty acid-containing triacylglycerols other than milk}

Although the milk of certain mammals is certainly the most abundant source of MCFA, they also occur in the fat of some seeds and plants (for example, Cuphea). They have been commercialized by many firms, and have slightly variable composition and are under different brands as tailored lipid sources; for example, Captex (Capital City Products, Columbus, OH, USA) and Neobee (Stepan Co., Maywood, NJ, USA). These MCTAG sources are almost pure and are prepared industrially from coconut and palmkernel oils by the enzymic or chemical esterification of glycerol with octanoic and decanoic acids.

\section{Possibilities, uses and side effects of medium-chain fatty acid-containing triacylglycerols and medium-chain fatty acids in nutrition}

Intact MCTAG have been used in human nutrition as an energy source, especially in clinical settings and parenteral feeding (premature infants, fat malabsorption syndromes, severe surgery, cancer), for approximately 50 years because of their unique properties. Their most important properties include the rapid and complete hydrolysis by lingual, gastric and pancreatic lipases and their beneficial effect on the intestinal mucosa. Other important properties are: their direct transport via the portal blood to the liver (without chylomicron formation or re-esterification); their preferential oxidation in the mitochondria to $\mathrm{CO}_{2}$ and ketone bodies (less dependence on carnitine) providing a rapidly available energy source (Velasquez et al. 1996).

However, in animals, an excess of non-esterified MCFA can have serious unwanted side effects, especially when given in high doses over a short time (for example, as a force-fed energy booster in the form of a lipid bolus). In neonatal piglets this can be ketogenic and narcotic (Samson et al. 1956; Lin et al. 1995). Also in man, the ingestion of $>30 \mathrm{~g}$ MCTAG in a short period of time induces nausea and gastrointestinal discomfort (Brouns \& Van der Vusse, 1998). Moreover, MCFA may be a stimulus to the secretion of cholecystokinin, and perhaps other intestinal hormones, resulting in a pronounced satiety action that could interfere with gastric emptying and feed intake (Mabayo et al. 1992, 1994). However, recent research has revealed that MCTAG have only minor effects on cholecystokinin release (Symersky et al. 2002). The strong goat-like odour (Molimard et al. 1997) and repellent taste of non-esterified MCFA (Cera et al. 1989b; Timmermann, 1993) can also be a cause of a lower feed intake. Salts of MCFA, on the other hand, may disturb the acid-base balance in the animal.

The authors of the present study thought that the in situ generation (for example, directly in the stomach) of diacylglycerols, monoacylglycerols and MCFA from intact MCTAG could avoid these side effects and so should always be highly preferred above the direct supplementation of the diet with non-esterified MCFA or their salts. Also because of the more prolonged retention time in the stomach and a slower absorption rate, a stronger antimicrobial efficacy of monoacylglycerols above non-esterified MCFA can be expected (Kabara et al. 1972; Kabara, 1984; Isaacs et al. 1990, 1995).

This was the origin of the authors' studies on the influences of the combined feeding of MCTAG together with an appropriate lipase, of which the origin can be various, but preferably easily commercially available. These commercial lipases are quite different in origin: plants (wheat, cas- 
tor bean, rapeseed, mustard); animals (pre-gastric esterase and rennet paste from calf, kid and lamb); micro-organisms (Candida, Rhizopus, Penicillium, Pseudomonas) (Pandey et al. 1999).

The present paper summarizes the concept, possibilities and limitations of applying TAG containing MCFA in combination with lipases as an alternative to in-feed antibiotics in piglets. The results presented here concerning the development of the concept are mostly based on the authors' research, recently published in detail elsewhere (Dierick \& Decuypere, 2002; Dierick et al. 2002a,b, 2003), but more emphasis is put in the present review on the possibilities and limitations. To the authors' knowledge, no data in the literature are available regarding the simultaneous use of specific intact MCTAG and lipolytic enzymes in animal nutrition for the purposes of growth promotion.

Although the energetic evaluation of the MCFA was not part of the authors' experiments, the metabolic and dietary aspects of the use of MCTAG and MCFA (effects on digestive physiology, gut flora, feed intake, performance, carcass composition) are also highlighted in the present overview. In addition, the role of preduodenal lipase activity, the presence of endogenous plant and microbial lipase activity in feedstuffs and the potential for exogenous lipase addition to the feed are discussed, leading to an optimal application of the concept.

\section{Development and validation of the concept}

\section{Efficacy in vitro}

An in vitro screening was carried out with a selection of commercial lipases for studying their activity on different MCFA containing natural or synthetic substrates (Dierick et al. 2002a). The conditions prevailing in vivo in the stomach of piglets (for example, an acid $\mathrm{pH}$ range of 3 to 6 , a coarse emulsified state of the fat source, the presence of inhibiting components in the diet, the presence of pepsin and gastric flora, a mean retention time of $3 \mathrm{~h}$ ) were simulated as much as possible. This was to avoid bias induced by the use of unnatural standard procedures. In the first set of experiments, lipolysis was studied with four selected MCFA-containing fat sources. These were: coconut oil; MCTAG1 (Aldo; Lonza Inc., Fair Lawn, NJ, USA); MCTAG2 (Stabilox; Loders Croklaan B.V., Wormerveer, The Netherlands); butter oil. Six lipases of different origin were used (L1-L6; microbial, porcine and calf pancreas). Depending on the conditions, up to $20 \%$ of the MCFA could be enzymically released in the medium. From these studies it is clear that some of the lipases tested are acid- and pepsin-resistant and that appropriate amounts of MCFA could be liberated to control the bacterial population, indicating that they could be an alternative to in-feed antibiotics.

In a second set of experiments (Dierick et al. 2002a), the generation and antimicrobial effects of MCFA from three selected MCFA-containing fat sources (coconut oil, MCTAG1, and MCTAG2) and one selected effective microbial lipase (L5), applied under different combinations and concentrations, were studied. A minimal concentration of $0.35 \mathrm{~g} / 100 \mathrm{~g}$ incubation fluid or $0.025 \mathrm{M}-\mathrm{MCFA}$ in the medium (for example, stomach, proximal gut) seems necessary in order to obtain a significant ( $>10$-fold) suppression of the flora (total anaerobic count, Escherichia coli), corresponding to $0 \cdot 025 \mathrm{M}$-non-esterified MCFA in the medium. This amount can be obtained by selecting an appropriate combination of sources and doses of fat and lipases (Table 3 ). The inhibitory effect on the flora of the fat sources used decreases further (MCTAG1 oil > MCTAG2 oil > coconut oil) with an increase in the molecular weight of the most important MCFA present in the TAG used. There was also a correlation between microbial growth inhibition and the lipophilic character of the fatty acids. This was also reported by Freese et al. (1973) and Sheu et al. (1975); 5-10 mM-C6 : 0 and -C8 : 0 were needed for 50\% growth inhibition of E. coli, while for C10 : 0 and $\mathrm{C} 12$ : 0 the minimum inhibitory concentration value was $>10 \mathrm{~mm}$. Because the $\mathrm{pKa}$ (acid strength) of MCFA is about 4.9 and the $\mathrm{pH}$ in the piglet stomach (fed ad libitum) ranges between 3 and 6 (N Dierick and J Decuypere, unpublished results), it can be accepted that most of the MCFA will be undissociated. In the more fat-soluble (undissociated) form, they can freely penetrate through the semi-permeable peptidoglycan (Grampositive) or phospholipid (Gram-negative) membrane of the micro-organisms into the cytoplasm by passive diffusion, as originally formulated by Jacobs (1940). In the cell, dissociation into proton and anion, due to the alkaline $\mathrm{pH}$ in the cytoplasm, will lower $\mathrm{pH}$, suppress cytoplasmic enzymes and nutrient transport systems and uncouple ATPdriven pumps, leading to cellular death (Freese et al. 1973; Hsiao \& Siebert, 1999). The inhibitory doses found in the present experiment agree well with the concentrations (25-30 mM) of acids proposed for inhibiting the growth of Gram-positive and Gram-negative microbes in food (Freese et al. 1973; Ostling \& Lindgren, 1993), pharmaceutical preparations (Kabara, 1984) and silages (Woolford, 1975). Nevertheless, those bacterial species are very different from the normal dominant species in the pig gut. Using a mathematical model based on principal component analysis, Hsaio \& Siebert (1999) obtained minimum inhibitory concentration values for caproic, caprylic and capric acids of $2 \cdot 2,3 \cdot 4$ and $19 \cdot 3 \mathrm{~g} / 1$ for $E$. coli in food. Their experiments confirm very well our findings and the importance of the pKa, molecular weight and the polarity of the MCFA.

\section{Efficacy in vivo}

A first in vivo experiment (Dierick et al. 2002b) was set up to verify whether the results obtained in vitro could also be obtained in situ in gastric-cannulated piglets. Indeed, the addition (5\%) of MCTAG (coconut oil, MCTAG1 oil, butter oil) to piglet diets in combination with selected lipolytic enzymes (1000 parts per million, in the feed) clearly regulated and stabilized the gastrointestinal flora in the stomach. It was striking that the extent of release of MCFA in the stomach corresponded closely to the degree of suppression of the bacterial load in the stomach (Table 4). The most pronounced reduction in total bacterial load in the stomach occurred with $1.01 \mathrm{~g}$ non-esterified fatty acids (NEFA)/100 g fresh contents (equivalent to $60 \%$ hydrolysis of the fat) or $0.68 \mathrm{~g} \mathrm{MCFA} / 100 \mathrm{~g}$ obtained with MCTAG1 oil + L5, followed by coconut oil + L5, by which $0.82 \mathrm{~g}$ NEFA or 
Table 3. In vitro release of medium-chain fatty acids (MCFA) from different fat sources under different incubation conditions and their effect on bacterial growth in gastric-simulating conditions (Dierick et al. 2002a)

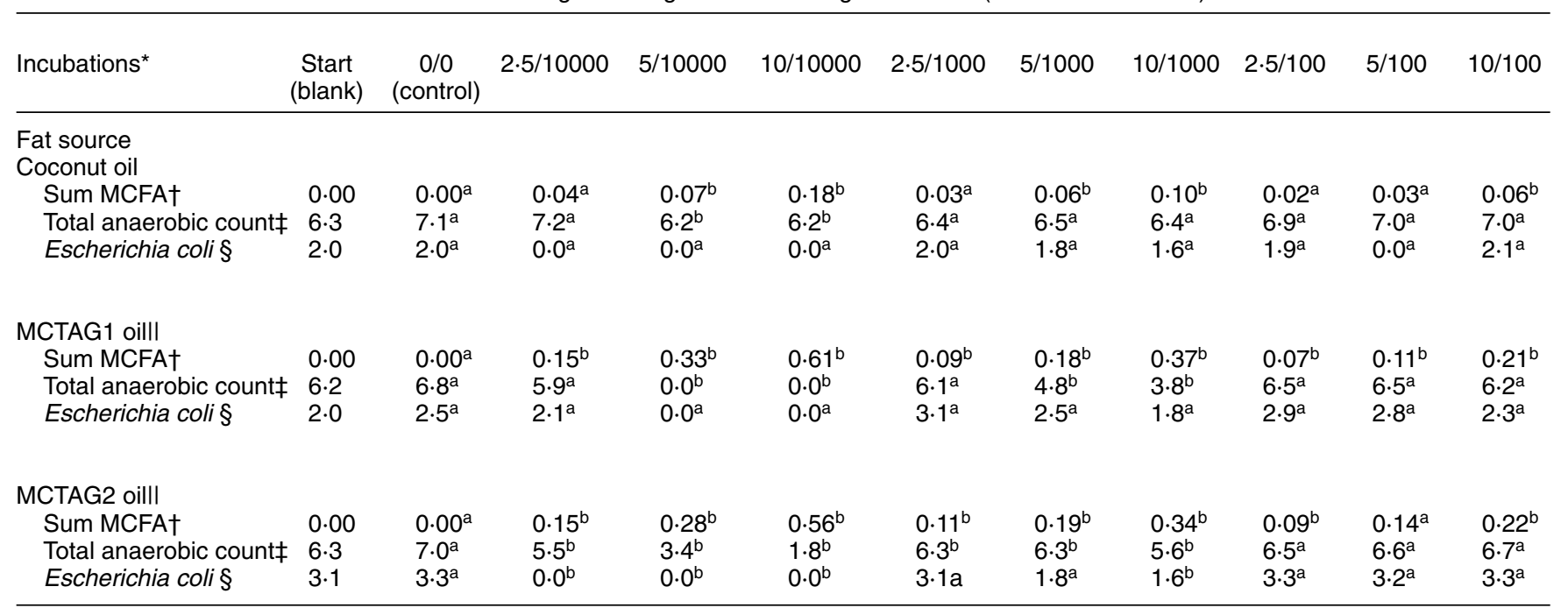

MCTAG, medium-chain fatty acid-containing triacylglycerols.

a,b Mean values within a row with unlike superscript letters were significantly different from control (condition $0 / 0)(P<0.05)$.

* Incubation time ( $3 \mathrm{~h})$ and conditions (percentage fat content in medium and lipase dose (parts per million of fat)). The lipase used was 'L5', of microbial origin (6563 U/g; Kemin Europa, Herentals, Belgium).

† Release of MCFA in the medium ( $\mathrm{g} / 100 \mathrm{~g}$ incubation fluid).

‡ Reinforced Clostridial agar medium for total anaerobic count (colony-forming units $\log _{10} / \mathrm{ml}$ incubation fluid).

$\S$ Eosin Methylene Blue agar for E. coli count (colony-forming units $\log _{10} / \mathrm{ml}$ incubation fluid).

II MCTAG1 contained (g/100 g fat): C4:0, 0.00; C6:0, 2.70; C8:0, 67.20; C10:0, 26.90; C12:0, 0.40. MCTAG2 contained (g/100 g fat): C4:0, 0.00; C6:0, 0.16; C8:0, 53.69; C10:0, 39.50; C12:0, 0.29.

$0 \cdot 30 \mathrm{~g}$ MCFA $/ 100 \mathrm{~g}$ was released. Butter oil $+\mathrm{L} 5$ had the least activity with $0.73 \mathrm{~g}$ NEFA or $0.06 \mathrm{~g}$ MCFA/ $100 \mathrm{~g}$ gastric contents.

\section{Confirmation of the in vivo results}

It is clear that in the in vivo experiment of Dierick et al. $(2002 b)$, the results obtained in the in vitro experiment were confirmed. However an additional validation of the results in more commercial settings was required. Therefore a combined growth trial and slaughter experiment with newly weaned piglets was set up (Dierick et al. $2002 b$ ). Four diets (A (negative control), $2.5 \%$ soyabean oil; B, $2.5 \%$ MCTAG2 oil; C, $2.5 \%$ MCTAG2 oil + 1000 parts per million lipase L5; D, $2.5 \%$ soyabean oil $+1.5 \%$ organic acids) were used. The last experimental group served as a positive control and was fed a combination of organic acids with a known and well-established growthpromoting effect. Otherwise they contained no other growth promoters.

From the slaughter experiment and bacterial counts, it could be concluded that there is a correlation between the amount of enzyme-released non-esterified MCFA and the extent of inhibition of the gastric and duodenal luminal flora (total count, Lactobacilli, E. coli) (Table 5). Calculations based on individual measurements (sum of non-esterified MCFA and the total anaerobic count in each sample) from both experiments further indicated the exis- tence of a correlation between the amount of released MCFA in the stomach and the inhibitory effect on the flora. The correlations were $r 0.86$ for MCTAG1 $(P<0.01)$; $r 0.83$ for MCTAG2 $(P<0.01) ; r 0.50$ for coconut oil $(P<$ $0 \cdot 05)$. This means that the higher the C8:0+C10:0 and the lower the C12:0 content in the MCFA profile in the fat source, the higher was the correlation.

\section{Efficacy in the field}

The in vivo experiment described earlier (Dierick et al. $2002 b$ ) was carried out in a commercial setting. The rest of the early weaned piglets were involved in a growth trial in which it was clearly demonstrated that the manipulation of the gut ecosystem by the enzymic in situ release of MCFA in the stomach and duodenum resulted in improved performance (Dierick et al. 2002b, 2003; Tables 5 and 6). An increase in daily gain of more than $10 \%$, combined with a $3 \%$ better feed conversion with the diets containing MCTAG2 oil or MCTAG2 oil + lipase was obtained, exceeding the performance observed with the control diets based on soyabean oil, supplemented or not with organic acids (Table 6).

In a search for an alternative to commercial MCTAG oils, which are rather expensive and industrially produced, the effects of adding a combination of milled Cuphea seeds, as a natural source of MCFA ( $75 \% \mathrm{C} 10: 0$ in the fat content), together with an exogenous lipase (500 parts per 


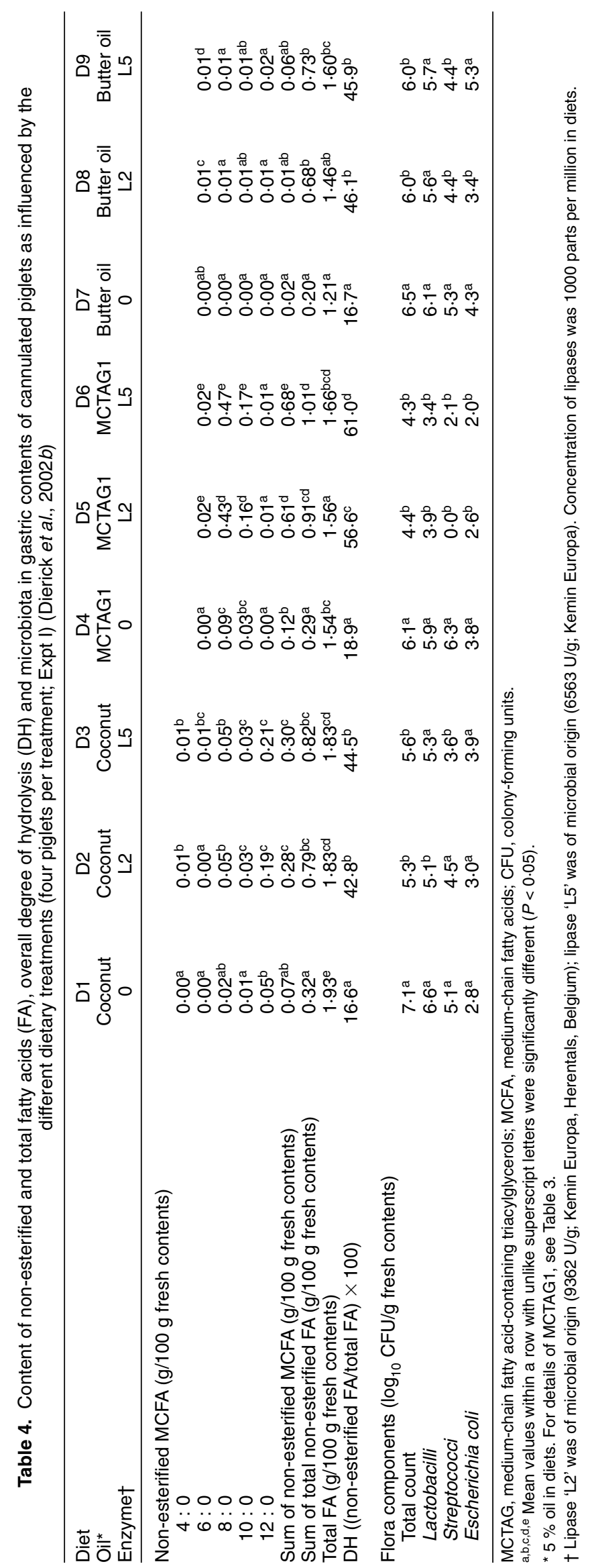


Table 5. Effect of the diet on the content of non-esterified and total fatty acids (FA) and overall degree of hydrolysis (DH) in gastric contents of slaughtered weaning piglets; effects on the gastric and duodenal flora (five piglets per treatment) (Expt II) (Dierick et al. 2002b)

\begin{tabular}{|c|c|c|c|c|}
\hline $\begin{array}{l}\text { Diet } \\
\text { Oil* }^{*} \\
\text { Lipase } † \\
\text { Organic acids } \ddagger\end{array}$ & $\begin{array}{c}\text { A } \\
\text { Soya } \\
0 \\
0\end{array}$ & $\begin{array}{c}\text { B } \\
\text { MCTAG2 } \\
0 \\
0\end{array}$ & $\begin{array}{c}\text { C } \\
\text { MCTAG2 } \\
\text { L5 } \\
0\end{array}$ & $\begin{array}{c}\text { D } \\
\text { Soya } \\
0 \\
\text { Mixture }\end{array}$ \\
\hline \multicolumn{5}{|l|}{ Non-esterified MCFA (g/100 g fresh contents) } \\
\hline $6: 0$ & 0.00 & 0.00 & 0.00 & 0.00 \\
\hline $8: 0$ & $0.00^{a}$ & $0 \cdot 13^{b}$ & $0 \cdot 26^{c}$ & $0.00^{a}$ \\
\hline $10: 0$ & $0.01^{a}$ & $0.07^{\mathrm{b}}$ & $0.17^{\mathrm{c}}$ & $0.00^{\mathrm{a}}$ \\
\hline Sum of total non-esterified FA ( $\mathrm{g} / 100 \mathrm{~g}$ fresh contents) & $0.28^{a}$ & $0.44^{\mathrm{a}}$ & $0.95^{\mathrm{b}}$ & $0.31^{\mathrm{a}}$ \\
\hline Total FA ( $\mathrm{g} / 100 \mathrm{~g}$ fresh contents) & $1.05^{a}$ & $1 \cdot 25^{\mathrm{ab}}$ & $1 \cdot 35^{\mathrm{b}}$ & $1.07^{\mathrm{a}}$ \\
\hline $\mathrm{DH}(($ non-esterified FA/total FA $) \times 100)$ & $26 \cdot 7^{a}$ & $35 \cdot 2^{\mathrm{a}}$ & $70 \cdot 4^{b}$ & $28 \cdot 9^{a}$ \\
\hline \multicolumn{5}{|l|}{ Flora components $\left(\log _{10} \mathrm{CFU} / \mathrm{g}\right.$ fresh contents) } \\
\hline $\begin{array}{l}\text { Stomach } \\
\text { Total count }\end{array}$ & $7 \cdot 0^{\mathrm{a}}$ & $7 \cdot 0^{\mathrm{ac}}$ & $5.9^{\mathrm{b}}$ & $6 \cdot 9^{\mathrm{ac}}$ \\
\hline Lactobacilli & $7 \cdot 2^{\mathrm{ac}}$ & $7 \cdot 6^{\mathrm{a}}$ & $6 \cdot 6^{\mathrm{bc}}$ & $7 \cdot 3^{\mathrm{a}}$ \\
\hline Lactobacilli & $6 \cdot 9$ & $6 \cdot 8$ & $5 \cdot 9$ & $6 \cdot 4$ \\
\hline Streptococci & $1 \cdot 6^{\mathrm{a}}$ & $0.0^{\mathrm{a}}$ & $4 \cdot 7^{\mathrm{b}}$ & $4.7^{\mathrm{b}}$ \\
\hline E. coli & $4 \cdot 9^{\mathrm{a}}$ & $4 \cdot 8^{\mathrm{a}}$ & $1 \cdot 8^{\mathrm{b}}$ & $1.8^{\mathrm{b}}$ \\
\hline
\end{tabular}

MCTAG, medium-chain fatty acid-containing triacyglycerols; MCFA, medium-chain fatty acids; CFU, colony-forming units.

a,b,c Mean values within a row with unlike superscript letters were significantly different $(P<0.05)$.

* $2.5 \%$ oil in diets. For details of MCTAG2, see Table 3.

† Lipase 'L5' was of microbial origin (6563 U/g; Kemin Europa, Herentals, Belgium). Concentration was 500 parts per million in diets.

$\$ 1.5 \%$ mixture containing $25 \%$ citric acid, $75 \%$ fumaric acid, $50 \%$ calcium formate.

Table 6. Effect of diet on feed intake, growth rate and feed conversion ratio (FCR) of early weaned piglets* (A, $n 68 ; \mathrm{B}, n 61 ; \mathrm{C}, n 60$; $\mathrm{D}, n 55$ piglets) (Expt II) (Dierick et al. 2002b)

\begin{tabular}{|c|c|c|c|c|c|}
\hline Post-weaning period (d) & $0-7$ & $7-14$ & $14-21$ & $0-21$ & 0-21 (relative to A) \\
\hline \multicolumn{6}{|l|}{ Feed intake (g/d) } \\
\hline A (soyabean oil) $\dagger$ & 156 & 365 & 472 & 331 & 100 \\
\hline B (MCTAG2 oil) & 191 & 376 & 536 & 368 & 111 \\
\hline C (MCTAG2 oil + lipase & 180 & 391 & 533 & 361 & 110 \\
\hline D (soyabean oil + acid mix§) & 189 & 355 & 469 & 338 & 102 \\
\hline \multicolumn{6}{|l|}{ Growth rate $(\mathrm{g} / \mathrm{d})$} \\
\hline A (soyabean oil) & $127^{a}$ & $127^{a}$ & $300^{a}$ & $185^{a b}$ & 100 \\
\hline B (MCTAG2 oil) & $164^{\mathrm{b}}$ & $160^{\mathrm{b}}$ & $301^{\mathrm{a}}$ & $208^{\mathrm{a}}$ & 112 \\
\hline C (MCTAG2 oil + lipasef) & $165^{\mathrm{b}}$ & $161^{\mathrm{b}}$ & $297^{a}$ & $207^{a}$ & 111 \\
\hline D (soyabean oil + acid mix§) & $141^{\mathrm{ab}}$ & $123^{a}$ & $280^{a}$ & $181^{b}$ & 98 \\
\hline \multicolumn{6}{|l|}{ FCR (kg feed/kg live-weight gain) } \\
\hline A (soyabean oil) & 1.23 & $2 \cdot 88$ & 1.57 & 1.79 & 100 \\
\hline B (MCTAG2 oil) & 1.16 & 2.35 & 1.78 & 1.77 & 99 \\
\hline C (MCTAG2 oil + lipase $\neq$ ) & 1.09 & $2 \cdot 43$ & $1 \cdot 79$ & 1.74 & 97 \\
\hline D (soyabean oil + acid mix§) & 1.34 & $2 \cdot 89$ & 1.68 & 1.87 & 104 \\
\hline
\end{tabular}

MCTAG, medium-chain fatty acid-containing triacylglycerols.

a,b Mean values with unlike superscript letters were significantly different $(P<0.05)$.

* Mean live weight at weaning ( 3 weeks) (day 0) was 5.81 (sD 0.18$) \mathrm{kg}$.

† $2.5 \%$ oil in diets A-D. For details of MCTAG2, see Table 3.

$\ddagger$ Lipase 'L5' was of microbial origin (6563 U/g; Kemin Europa, Herentals, Belgium). Concentration was 500 parts per million in diet

$\S 1.5 \%$ organic acid mixture containing $25 \%$ citric acid, $75 \%$ fumaric acid and $50 \%$ calcium formate. 
million) in a weaner diet were studied (Dierick et al. 2003). There was no third treatment (either without lipase but supplemented with Cuphea or a control diet only lipase supplemented). This was because preliminary research revealed that MCFA from native fat in Cuphea seeds could not be liberated by pig endogenous gastric lipase alone (without extra added lipases), and that long-chain fatty acids, possibly liberated in the stomach by pig gastric lipase from normal fat sources (for example, soyabean oil) do not have any antimicrobial effect. The Cuphea seed mixture (Cuphea lanceolata and C. ignea) $(50 \mathrm{~g} / \mathrm{kg})$ was substituted for soyabean oil (15 g/kg), Alphacel (ICN Biomedicals Inc., Irvine, CA, USA; $25 \mathrm{~g} / \mathrm{kg}$ ) and soya protein isolate (10 $\mathrm{g} / \mathrm{kg}$ ) in the control diet. Overall, the piglets on the Cuphea diet showed an $8 \%$ higher feed intake, a $25 \%$ faster growth rate and a $14 \%$ better feed:gain ratio (Table 7). The differences were not significant however $(P=0 \cdot 19)$, probably due to the low number of animals and because Cuphea was in short supply, also limiting the length of the experiment. To the authors' knowledge, there is no information on the toxicity of this material (Graham, 1989). Very recently sterols, triterpenes, tannins and flavonoids have been described as the main secondary metabolites in some Cuphea cultivars (Perez-Castorena \& Maldonado, 2003). In our experiments (Dierick et al. 2003) however, an improved feed intake and no negative clinical symptoms were noted. One case has been reported of emaciation and death in quail after feeding whole $C$. carthegenensis seeds. The moisture in the crop caused the release of the mucilaginous seed hairs subsequently forming an impaction that blocked any further passage of food and ultimately led to the death of the birds (Hurst, 1978). Indeed, the inverted spiral hairs, probably glycoproteins containing primarily arabinose, ribose and xylose, become everted and highly mucilaginous upon soaking in water for 10 to $20 \mathrm{~min}$ (Stubbs \& Slabas, 1982). This could be the reason for the higher water content in the proximal gut contents of the piglets fed Cuphea seeds in our experiments (Dierick et al. 2003). Similar effects have been observed with the mucilage cells of linseed in broilers (Alzueta et al. 2002). Long-term feeding of crude Cuphea oil (8.5\% in the diet) over several generations did not cause any specific toxic effect in mice (Hendrich et al. 1993).
The enzymically released antimicrobial MCFA $(1 \cdot 7 \mathrm{~g} / \mathrm{kg}$ fresh gastric contents) decreased the number of coliforms in the proximal small intestine, Streptococci in the whole small intestine and Lactobacilli in the stomach and the proximal and distal small intestine. No effects were noted on the total anaerobic microbial load. Most probably, better results could have been obtained by using other Cuphea varieties (Graham, 1989), for example, $C$. pinetorum, $C$. hookeriana, $C$. painteri, C. cyanea, containing more than $50 \% \mathrm{C} 8: 0$ and $25 \% \mathrm{C} 10: 0$ in the fat fraction and/or by using a higher exogenous lipase activity for a better and faster release of the fat more proximally in the foregut. Indeed, the endogenous lipase activity in the ground seeds tested here was very low in comparison with that found in other pig-feed raw materials (cereals, legumes) (Dierick \& Decuypere, 2002; Dierick et al. 2003). In comparison with the control diet containing no extra lipase, feeding Cuphea + lipase further resulted in a significantly greater villus height (proximal small intestine) and a lesser crypt depth (proximal and distal small intestine), a greater villus:crypt ratio (proximal and distal small intestine) and a lower number of intra-epithelial lymphocytes (IEL) in the villous epithelium, which is indicative for a more healthy and well-differentiated intestinal mucosa (Table 8). IEL are Tlymphocytes, mainly of the $\mathrm{CD} 8^{+}$phenotype, of which the functions have not been entirely elucidated. It is accepted that they play a central role as a first line of defence against foreign luminal antigens (pathogens, proteins), in the induction of apoptosis of epithelial cells and in the conservation of the mucosal integrity (Vega-Lopez et al. 2001). This is in line with the observations of Czernichow et al. (1996) showing that enterally infused MCTAG enhanced mucosal mass and favoured epithelial cell renewal in the proximal intestine in rats. The findings of a more slender villus structure in piglets when antibacterial growth promoters were added to the feed are possibly related to the same mechanism (Van Leeuwen et al. 2001). Potential interference arising from the mucilage-containing hairs and/or secondary plant metabolites (Salatino et al. 2000; Puupponen-Pimiä et al. 2002) of the Cuphea seeds with the gut flora and/or the intestinal surfaces cannot be excluded but further research is required to elucidate this point.

Table 7. Effect of feeding whole Cuphea seeds and lipase on the zootechnical performances of early weaned piglets (fifteen piglets per treatment) (Expt III) (Dierick et al. 2003)

\begin{tabular}{|c|c|c|c|c|c|}
\hline & \multirow[b]{2}{*}{ Diet } & \multicolumn{4}{|c|}{ Days post-weaning } \\
\hline & & $0-7$ & $7-14$ & $14-16$ & $0-16$ \\
\hline Feed intake (g/d) (per pen) & $\begin{array}{l}\text { Control } \\
\text { Cuphea + lipase* }\end{array}$ & $\begin{array}{l}212 \\
194\end{array}$ & $\begin{array}{l}360 \\
396\end{array}$ & $\begin{array}{l}489 \\
607\end{array}$ & $\begin{array}{l}311 \\
336\end{array}$ \\
\hline Growth (g/d) (individual) & $\begin{array}{l}\text { Control } \\
\text { Cuphea + lipase } \\
P \text { value }\end{array}$ & $\begin{array}{l}135 \\
135 \\
1.00\end{array}$ & $\begin{array}{l}242 \\
298 \\
0 \cdot 19\end{array}$ & $\begin{array}{l}311 \\
389 \\
0.25\end{array}$ & $\begin{array}{l}205 \\
256 \\
0 \cdot 19\end{array}$ \\
\hline
\end{tabular}

FCR, feed conversion ratio; LWG, live-weight gain.

* The concentration of Cuphea seeds was 50 g/kg diet. Lipase 'L5' was of microbial origin (6563 U/g; Kemin Europa, Herentals, Belgium); concentration was 500 parts per million in diet. 
Table 8. Effect of feeding whole Cuphea seeds and lipase on the mean villus height (VH), crypt depth (CD) ( $\mu$ m) and number of intra-epithelial villous lymphocytes (IEL) in the proximal small intestine of weaned piglets (five piglets per treatment) (Expt III) (Dierick et al. 2003)

\begin{tabular}{|c|c|c|c|c|c|c|c|c|}
\hline \multirow[b]{2}{*}{ Diet } & \multicolumn{4}{|c|}{ Proximal† } & \multicolumn{4}{|c|}{ Distal† } \\
\hline & VH & CD & $\mathrm{VH} / \mathrm{CD}$ & IEL $\ddagger$ & VH & $C D$ & $\mathrm{VH} / \mathrm{CD}$ & IEL $\ddagger$ \\
\hline Control & 381.9 & $244 \cdot 2$ & 1.6 & 33.9 & $447 \cdot 7$ & $246 \cdot 6$ & 1.9 & $30 \cdot 3$ \\
\hline Cuphea + lipase§ & 365.7 & 201.0 & 1.9 & $26 \cdot 7$ & $507 \cdot 1$ & 235.2 & $2 \cdot 2$ & $26 \cdot 0$ \\
\hline Significance or $P$ value & 0.14 & $* * *$ & $* * *$ & $* *$ & $\star \star \star *$ & $\star *$ & $\star \star \star *$ & 0.21 \\
\hline
\end{tabular}

The mean value for the Cuphea + lipase diet was significantly different to that for the Control diet: ${ }^{\star} P<0.05,{ }^{\star \star} P<0.01,{ }^{\star \star \star} P<0.001$.

† Sampled sites were $3 \mathrm{~m}$ distal from the pylorus and $3 \mathrm{~m}$ proximal of the caecum.

$\ddagger$ Number of IEL per 100 enterocytes.

$\S$ The concentration of Cuphea seeds was $50 \mathrm{~g} / \mathrm{kg}$ diet. Lipase 'L5' was of microbial origin (6563 U/g; Kemin Europa, Herentals, Belgium); concentration was 500 parts per million in diet.

Feeding swine with antibacterial growth promoters has been documented to increase weight gain by $3-9 \%$ and improve feed efficiency by 2-7\% (Thomke \& Elwinger, 1998a). The exact mechanisms by which this occurs are complex and not completely understood (Visek, 1978). The authors of the present study believe that the benefits of growth-promoting antibiotics result from a substantial decrease in bacterial load, whether commensal or pathogenic (Vervaeke et al. 1979) and the consequent direct or indirect alterations in epithelial functions (for example, increased villus height; decreased crypt depth) in the small intestine. This leads to an enhanced uptake and use of nutrients and an enhancement of the activity of the immune system (for example, decreased number of IEL) (Dierick et al. 1981, 1986b; Shurson et al. 1990; Decuypere et al. 1991; Li et al. 2001; Van Leeuwen et al. 2001). Furthermore, indigenous microbiota in the small intestine depress growth by competing with the pig for nutrients (glucose, amino acids) and by producing microbial metabolites $\left(\mathrm{NH}_{3}\right.$, amines, phenolic compounds, bile-acid deconjugation and degradation), increasing gut mucosa turnover and maintenance costs (Vervaeke et al. 1979; Dierick et al. 1986a,b; Anderson et al. 1999; Gaskins et al. 2002). Indeed, microscopic and histological evaluation of the germ-free intestine revealed a more regular and slender villus structure, a thinner lamina propria, a slower rate of renewal of epithelial cells and a very low, constant number of IEL (Ferguson, 1974; Coates, 1980).

It can be concluded that MCFA can be a valuable alternative to nutritional antibiotics because the same underlying factors affecting growth promotion are affected.

\section{Metabolic and dietary constraints for the use of intact (i.e. non-hydrolysed) medium-chain fatty acid- containing triacylglycerols alone or in combination with exogenous lipases in pig feeding}

Effects on production parameters: feed intake, growth rate, feed conversion and carcass composition

As mentioned above, MCFA are a readily available and easily metabolized source of energy. In order to increase the birth weight and vitality of the piglets, several authors have studied the nutritional effects of intact MCTAG or MCFA-containing fats in the diets of sows during late gestation. Most studies, however, deal with the performance of neonatal, weaned or growing pigs on diets containing intact MCTAG in comparison with commonly used fats.

Intact medium-chain fatty acid-containing triacylglycerols for pregnant sows. No differences were found in the productive efficiency of sows and growth of the sucking pigs between feeding MCTAG or long-chain fatty acid-containing TAG (LCTAG) in late gestation (Averette Gatlin et al. 2002).

However, Stahly (1983) and, more recently, Newcomb et al. (1991), Azain (1993) and Jean \& Chiang (1999) found an increased survival of neonatal piglets by supplementing the sow diet with MCTAG in comparison with soyabean oil. They explained the effects by citing increased blood glucose levels, enhanced glycogen stores and maturity of the piglets at birth. The 4-fold increase of the MCTAG in the sows' milk, which normally contains only traces of MCFA (Table 1), could also have been beneficial for the piglets in the pre-weaning period. However, the transfer of MCFA into milk fat by feeding sows with diets containing as much as $10 \%$ MCTAG remains rather low (2\% of total milk fat) (Newcomb et al. 1991; Azain, 1993).

Intact medium-chain fatty acid-containing triacylglycerols for neonatal and pre-weaning piglets. In his excellent reviews, Odle $(1997,1999)$ concluded that MCTAG should have the desired characteristics to supplement the low energy reserves in neonatal piglets and to increase their survival. However, the narcotic effect of high doses of MCTAG might cause piglets to be less vigorous and thus increase their mortality, especially with newborn piglets weighing less than $1 \mathrm{~kg}$ at birth.

Intact medium-chain fatty acid-containing triacylglycerols for post-weaning piglets. Also for post-weaning piglets, in which a growth lag of more than $14 \mathrm{~d}$, combined with a rise in mortality, is not uncommon, MCFA-containing fat sources may be beneficial, but again the results are rather inconsistent. With weaned piglets of $10 \mathrm{~kg}$ during a $21 \mathrm{~d}$ experimental period, Allee et al. (1972) did not find differences in feed intake, gain or gain:feed ratio with rations containing $10 \%$ MCTAG compared with tallow, lard, coconut oil or maize oil. This is in accordance with the results of Newport et al. (1979) with diets containing $15 \%$ MCTAG and pigs of 2 or $28 \mathrm{~d}$ old. Neither did Mahan 
(1991) find differences in performance comparing soyabean oil with coconut oil in the diet of early-weaned pigs. Furthermore, Fakler et al. (1992) did not observe differences in performance when weaned piglets were fed a diet containing $8 \%$ MCTAG or $10 \%$ soyabean oil. Recently, Léon et al. (1998) stated that the provision of MCTAG did not improve the energy status of the bottle-fed newborn piglet in comparison with LCTAG. On the other hand, Cera et al. (1989a) and Jin et al. (1998) found that coconut oil was superior for weaned piglets compared with soyabean oil, maize oil or tallow. These results agreed well with those of De Rodas \& Maxwell (1990) who obtained a significantly increased average daily gain, feed intake and feed efficiency during the first week post weaning (weaning at 21 to 28 d) by feeding $4 \%$ lard combined with $6 \%$ MCTAG oils, compared with $10 \%$ lard or butterfat. Finally, Dove (1993), feeding $5 \%$ soyabean oil, MCTAG or animal fat, obtained the highest growth rate with the MCTAG source. There are discrepancies between the effects of MCTAG on pig performance noted in most of the cited literature and the results obtained in the authors' research. These discrepancies may be related to the absence or very low levels of endogenous gastric or plant lipases, or to the fact that no exogenous lipases were added to the diets, resulting in levels of MCFA in the stomach and duodenum that were too low to influence the gut flora.

Intact medium-chain fatty acid-containing triacylglycerols for growing pigs and pre-ruminant calves. In growing pigs (30-90 kg), Glaps (1970) did not observe any difference in performance when feeding $2 \mathrm{ml} \mathrm{MCTAG/d} \mathrm{per} \mathrm{kg}$ compared with LCTAG. This was also the conclusion of Takada et al. (1992), feeding $8 \%$ MCTAG in comparison with $8 \%$ LCTAG. However, substituting part of the tallow in the milk replacer by tricaproin or tricaprylin, combined with coconut oil, for preruminant calves resulted in a $30-40 \%$ increase in growth rate and energy efficiency (Aurousseau et al. 1984).

Feeding non-esterified MCFA instead of feeding intact (i.e. non-hydrolysed) MCTAG to weaned piglets had no effect (Cera et al. 1989b), but with growing pigs Rys et al. (1969/70) fed $5 \%$ pure non-esterified MCFA (C5-C12) and obtained an increase in the growth rate of $6 \%$, in comparison with an isoenergetic control diet. The lack of a positive effect of non-esterified MCFA in young pigs may be related to the fatty acid level and profile of the fat sources used and to negative effects on feed intake, as mentioned earlier.

\section{Effects on product quality}

The concept of using TAG containing proper amounts of MCFA combined with exogenous lipolytic enzymes as an alternative to nutritional antibiotics has initially been targeted at piglet and early grower nutrition. However, applying higher doses of MCTAG, alone or in combination with lipases, with the objective to increase the energetic value of the pig feed, may selectively increase the firmness of the carcass fat by MCFA chain elongation (Takada et al. 1992). In order to avoid increases in the degree of saturation of the carcass fat in slaughter pigs and because the major changes in fatty acid composition due to diet influences will occur within 4-5 weeks (Wiseman \& Agunbiade, 1998), high levels of MCTAG (4\% or more) are not recommended in the finishing phase of pigs.

Finally, some reports indicate that high levels of MCFA in the diet may reduce the deposition of fat and decrease protein catabolism in mammals, poultry and fish (Aurousseau et al. 1984; Crozier et al. 1987; Chiang et al. 1990b; Mabayo et al. 1993; Røsjø et al. 2000). This may be related to the lower gross energy and net energy content $(-20 \%)$ of MCTAG (gross energy of 34.9 and net energy of $28.6 \mathrm{~kJ} / \mathrm{g}$ ) compared with LCTAG (Ingle et al. 1999).

\section{Effects on the gastrointestinal mucosa and physiology}

Bacteria differ from eukaryotic cells in that they have rigid cell walls. Sheu et al. (1975) reported growth inhibition and morphological alterations in mammalian cell cultures (HeLa, human fibroblasts and mouse neuroblastoma cells) by millimolar concentrations of C6-C10 fatty acids, most probably due to alterations in cell attachment structures or processes. Nevertheless, Odle et al. (1991), studying the metabolism of even- and odd-C MCFA as $\mathrm{Na}$ salts $(1 \mathrm{mmol} / \mathrm{l})$ in isolated piglet hepatocytes, did not mention any alterations. However several authors warned of epithelial cell damage and disorders in phospholipid bilayers and membranes by MCFA and related compounds (Wargovich et al. 1984; Van Hoogdalem et al. 1989; Bergner \& Sommer, 1994; Shima et al. 1998, 1999; Kimura et al. 2001). Kanai \& Kondo (1979) concluded that, because MCFA and their acylglycerols are anionic surface-active compounds, in vitro cytotoxicity and membrane disorders and perturbations in tissue culture cells can occur. However, it is generally believed that the same events would not occur in living bodies in which various neutralizing agents such as serum, chyme and mucins are abundant. A higher susceptibility of isolated cells in vitro compared with tissue-associated cells in a natural environment was also observed with volatile fatty acids (Wächtershäuser \& Stein, 2000).

Today, based on clinical observations in human subjects, it is clear that MCTAG and MCFA may have several positive effects on gut physiology. First, they improve intestinal morphology and function, through their positive effects on crypt cell activation and reactive villous hyperplasia (malnutrition, ageing) (Galluser et al. 1993; Jenkins \& Thompson, 1993; Czernichow et al. 1996; Iba et al. 1998). Second, they have positive effects on epithelial cell membrane-bound enzyme activities (Takase \& Goda, 1990). Third, they enhance absorption as measured in Caco- 2 cell monolayers (Lindmark et al. 1995, 1998). Fourth, they are an excellent fuel as a source of acetate for small-intestinal enterocytes (Greenberger et al. 1965; Guillot et al. 1993) and a more suitable energy source than LCFA for epithelial cells in the treatment of Crohn's disease (Andoh et al. 2000). As already mentioned, Odle $(1997,1999)$ did not indicate any deleterious effect of MCFA when studying their metabolism in isolated hepatocytes of neonatal piglets. Finally, Traul et al . (2000) reviewed the toxicological prop- 
erties of MCTAG for pigs. There was no evidence that dietary administration of MCTAG adversely affected the reproductive performance of sows or resulted in maternal or fetal toxicity and teratogenic effects in doses up to $4 \mathrm{~g} / \mathrm{kg}$ live weight per $\mathrm{d}$ in the diet, in accordance with the results of Hendrich et al. (1993) obtained with three generations of mice. For all these reasons, negative effects of MCFA on host epithelial cells are unlikely. This is in line with our results (Dierick et al. 2003) where an increased villus:crypt ratio and a lower number of IEL, indicative of a more healthy and better functional status of the mucosa, was observed when feeding a Cuphea + lipase-containing diet to weaned piglets. It can be argued that the combined use of TAG and lipases reduces the potential for tissue irritation and toxicity that could be produced by the ingestion of large amounts of ionized NEFA together with large quantities of damaging cations such as $\mathrm{Na}^{+}$(Bergner \& Sommer, 1994; Wächtershäuser \& Stein, 2000).

Although MCTAG and MCFA are 'generally regarded as safe' (GRAS) and of benefit for oral and enteral use in human nutrition by the Food and Drug Administration in the USA, their effects on mucosal integrity need further in vivo research, especially with large doses or sudden incorporation in the diet.

\section{Gut flora, pathogens and resistance}

The antibacterial mechanism(s) of organic acids and SCFA are not fully understood and activity may vary depending on the growth phase of the organism and on environmental characteristics. An autolytic enzyme (autolysin) seems to be involved in the bacterial death and cellular lysis induced by MCFA (Tsuchido et al. 1985). The fate of MCFA, once inside the microbial cell, is not clear. According to Fay \& Farias (1975), MCFA are not metabolised by E. coli. In contrast, Cherrington et al. (1991) claimed that Gram-negative bacteria are capable of metabolising MCFA. According to these authors, MCFA penetrate the membrane via porins and once inside the cell they should be degraded via the $\beta$ oxidation cycle, of which the necessary enzymes are induced by the acid.

At present there is some evidence that (potentially) pathogenic bacteria may be inactivated by MCFA or their monoacylglycerols (Kabara et al. 1972; Kabara, 1984; Isaacs et al. 1990, 1992; Boddie \& Nickerson, 1992; Wang \& Johnson, 1992; Guthery, 1993; Oh \& Marshall, 1993; Kinderlerer et al. 1996; Petrone et al. 1998; Petschow et al. 1998; Sprong et al. 2002).

An emerging potential problem is that organic acids and SCFA have been observed to enhance the survivability of acid-sensitive food-borne pathogens (Salmonella, E. coli, Listeria, etc) exposed to low $\mathrm{pH}$ (gastric contents) by the induction of an acid-tolerance response, linked to an increased virulence (Ricke, 2003). According to Petschow et al. (1998), it is important to note that MCFA do not induce a notable resistance and, in any case, the induction of resistance must be very low in comparison with antibiotics. The exact mode of action of MCFA in inhibiting the growth and colonization of pathogens (E. coli, Salmonella, Serpulina, Clostridium, etc) needs to be further elucidated, however.

\section{Role of preduodenal lipases in the release of medium-chain fatty acids in the stomach and proximal gut}

In most mammals there is a more or less pronounced preduodenal lipase activity, originating from lingual or gastric secretions. These lipases are active in a broad $\mathrm{pH}$ range with a preference for MCFA in milk fat (Table 2). Endogenous gastric lipase (optimal pH range 5-9; Höller, 1970) located in the cardiac region of the pig stomach, is thought to play a significant role in the hydrolysis of fats in the stomach but its quantitative contribution to overall fat digestion still remains to be elucidated. The enzyme seems to be resistant to acid and pepsin and its action is independent of bile acids or cofactors. The degree of fat hydrolysis (17 \% NEFA in total fat, Table $4 ; 25-35 \%$ NEFA in total fat, Table 5) noted in the stomach of piglets after feeding diets without added lipases is in accordance with the scarce literature data (Newport \& Howarth, 1985; Chiang et al. 1990a). Jensen et al. (1997) followed the development of lipases in pigs and noted a pronounced decrease in pancreatic and an increase in stomach lipase activity (only $0.2 \%$ of the pancreatic activity) in newly weaned piglets. Höller (1970) estimated the gastric lipase activity to be only $5 \%$ of the pancreatic lipase activity, while Newport \& Howarth (1985) reported that the total lipase activity in stomach tissue was only about $3 \%$ of that found in the pancreas. Recently Li et al. (2001), investigating the development of lipase in nursing piglets, reported that total gastric lipase activity was fully developed on day 21 , but reached only about $5 \%$ of the pancreatic lipase activity at that time. However, the fact that fatty digesta are retained for a longer time in the stomach than in the small intestine could explain why gastric lipase, despite its low activity, may actually hydrolyse a considerable part of the fat in the stomach. Furthermore, Hunt \& Knox (1986) found that fatty acids are more effective than the corresponding TAG in delaying gastric emptying and that increasing the chain length up to C14:0 (primarily MCFA) led to a progressively slower emptying. Gastric lipase also remains active in the duodenum, acting in synergy with pancreatic lipase (Edwards-Webb \& Thompson, 1977).

However, it appears that this endogenous lipase activity in the stomach of piglets is too low (with a degree of hydrolysis of 15-30\%; Tables 4 and 5) to generate enough MCFA $(0.025 \mathrm{M})$ to control the gut flora. This could be related to the lower (4-5) than optimal $\mathrm{pH}$ (5-9) for pig gastric lipase activity. As no contaminating bacteria were detected in any of the prepared feeds, lipolytic activity from microbial origin also seemed unlikely. Therefore, the addition of exogenous lipolytic activity, through lipase supplementation of the diet, with an optimal $\mathrm{pH}$ in the acid range (4-5), seems to be advantageous for releasing sufficient amounts of MCFA for an effective antimicrobial activity.

\section{Role of endogenous lipases, originating from raw materials, in the release of medium-chain fatty acids in the stomach and proximal gut}

Besides preduodenal lipases, a second source of endogenous lipases, originating from raw materials or prepared 
feeds, may interfere with the application of the concept. Information on endogenous lipolysis in raw and processed materials during storage is very scarce (O'Connor et al. 1992). Plant seeds store TAG in intracellular organelles called oil bodies or oleosomes, which are oil droplets covered by a coat of phospholipids and proteins serving as high-energy $\mathrm{C}$ reserves (Beisson et al. 2001). Lipolysis and subsequent rancidity caused by oxidation is usually not a problem in intact whole grains or seeds, stored at normal temperature $\left(<20^{\circ} \mathrm{C}\right)$ and moisture levels $(<12 \%)$. During germination and in sprouted, cracked, broken or ground seeds, however, lipase activity may increase considerably. Subsequently, it is evident that the NEFA content of milled feedstuffs, raw materials and compound feeds and the subsequent lipolysis during the storage of compound feeds are important parameters, which will influence the subsequent nutritional and economic value of the fat and the feed.

From the authors' own results, NEFA levels of more than $50 \%$ in the lipid fraction were found in milled raw materials and in compound feeds, after a few weeks of storage. Normally endogenous lipolysis remains low (5-15\% NEFA in fat) in stored heat-treated cereals, in milk (products), fish products and Cuphea seeds (Dierick \& Decuypere, 2002; Dierick et al. 2003). It is recommended that lipolysis should be prevented both in feedstuffs and compound feeds during storage. Indeed, most post-weaning diets are supplemented with fats and oils to increase palatability and energy intake. For the application of the proposed concept, preference should be given to heat-treated raw materials or mixed feeds (for example, pelleting, expansion, extrusion), showing no or low levels of endogenous lipase activity. Also an appropriate choice of the exogenous lipase used can greatly influence the subsequent lipolysis in the compound feed and is essential in order to prevent any aggravation of the inevitable endogenous lipolysis in the feed. The release of small amounts of MCFA during the storage of feed is not disadvantageous per se, however, because it can prevent the growth of deleterious microbial contaminants in the feed before ingestion. High amounts of non-esterified MCFA, however, may produce an adverse odour, as already mentioned.

The question may arise as to whether the lipase activity results, entirely or in part, from surface-associated microorganisms such as Penicillium, Pseudomonas and Candida, rather than from the feedstuff itself, as suggested by Petterson et al. (1999). However, the total microbial count on the feeds and feedstuffs used in all our experiments (Dierick et al. 2002a,b) was about 1000 colony forming units/g. A simple calculation indicates that such populations are much too small to contribute significantly to lipolytic activity, which is in line with the results of Petersen (1999).

Our results clearly demonstrate that the activity of all those endogenous lipases (preduodenal, plant raw materials, in-feed microbes) in normal circumstances (fresh feed; piglets in post-weaning period) is too low for releasing sufficient amounts of MCFA for the antimicrobial management in the stomach and foregut of piglets.

\section{Mode of application}

The antibacterial activity of the classic non-esterified organic acids can be reduced by a decrease in feed intake, because some of them (for example, propionic acid) have a bad taste. This is very important in early-weaned pigs where feed intake is already seriously impaired. Another cause for reduced efficacy is the direct absorption in the stomach and upper small intestine (Clark et al. 1969; Dierick et al. 2002b). Moreover, the use of some of these acids (acetic acid, formic acid) is limited by problems of handling, strong odour and corrosion during feed processing and during its use on the farm. The use of specific preparations that gradually release the active acids (for example, micro-encapsulated or protected acids) at the desired site of action represents a strategy to overcome this problem (Cerchiari, 2000). Taking all these arguments into consideration, a gradual enzymic release of MCFA, eventually together with MCFA-containing monoacylglycerols from TAG, in situ in the foregut, seems to be preferable to the supplementation of the feed with fixed doses of more common organic acids or MCFA or their salts. This mode of application avoids taste aversion, disturbance of the acid-base balance or possible mucosal damage, which can also decrease performance (Ostrowski et al. 1972).

\section{Concluding remarks and needs for further research}

During the last decade a lot of research has been directed to the use of MCTAG in human and animal nutrition, especially for piglets. Almost no research has been focused, however, on their use as a potential source of antimicrobial compounds, when liberated in situ in the stomach and foregut by appropriate lipases.

The present review illustrates similarly strong activity of MCFA and the classical antimicrobial growth promoters and therapeuticals on the gut flora (total flora, Gram-positive flora, Gram-negative flora, potential pathogens) especially in the stomach and the foregut, as well as on the gut function of piglets. This means that these naturally occurring antimicrobial agents, which have little or no toxicity, can be an effective alternative to in-feed antibiotics.

A progressive enzymic release of MCFA, eventually combined with MCFA-containing monoacylglycerols from $\mathrm{TAG}$, in situ in the foregut, seems to be preferable to the supplementation of the feed with non-esterified classical organic acids or non-esterified MCFA or their salts, avoiding taste aversion and disturbance of the acid-base balance in the animal.

However, when applying this concept, the choice of feedstuffs and lipases should be done very carefully and needs further exploration.

Because the recovery rates of bacteria by classical culturing methods, as compared with direct microscopic counts, have been reported to range from 30 to $60 \%$, more research is needed based on molecular techniques. There are three techniques used extensively in microbial ecology, based on the variability in the $16 \mathrm{~S}$ rRNA-gene (rDNA) or on the use of specific primers and probes based on 16S rRNA: fluorescent in situ hybridization, quantitative polymerase chain reaction and denaturing gradient gel electrophoresis or tem- 
perature gradient gel electrophoresis (Snel et al. 2002). These techniques most probably will provide more precise identification and enumeration of microbial populations, independent of cultivating on plates. They will enable a reassessment of the microbial ecology of the pig gastrointestinal tract (Simpson et al. 1999; Van Den Bossche et al. 2001; Leser et al. 2002; Akkermans et al. 2003) and the microbial populations as altered by growth-promoting antibacterials (Gaskins et al. 2002), including MCFA. As there are also limitations to these molecular techniques, a complete picture of the diversity and the role of the complex microbial ecosystem in the pig gut will need a combination of both classical and molecular techniques (Knarreborg et al. 2002).

The role and potential of MCFA in inhibiting the growth and colonization of an autochthonous microflora, including food-borne pathogens (E. coli, Salmonella, Clostridium, etc) needs further investigation, especially with regard to the possible induction of acid tolerance, mechanisms of resistance and linked virulence.

More attention should also be given to meat quality, especially when applying high doses of MCTAG in growing and finishing pig diets.

Alternatives to the common sources of MCTAG oils, which have the very serious constraint of being rather highly priced, should be explored.

Finally, as the concept is not limited to a specific medium, further development in warm-blooded production and companion animals and in cold-blooded animals as well as in plants for treatment of microbial infections awaits further research.

\section{Acknowledgements}

Most of the cited own work was financially supported by the Belgian Ministry of Small Enterprises, Traders and Agriculture, General Direction for R\&D, N.V. Aveve (Belgium), N.V. Kemin Europa (Belgium) and N.V. Vitamex (Belgium). The authors would like to thank Dr C. Van Nevel for his help in the morphological and histochemical measurements and his valuable comments with regard to the text.

\section{References}

Akkermans A, Konstantinov S, Zhu W, Favier C \& Williams B (2003) Postnatal development of the intestinal microbiota of the pig. In Proceedings of the 9th International Symposium on Digestive Physiology in Pigs, vol. 1, pp. 49-56 [R Ball, editor]. Edmonton, Canada: University of Alberta.

Allee G, Romsos D, Leveille G \& Baker D (1972) Metabolic consequences of dietary medium-chain triglycerides in the pig. Proceedings of the Society for Experimental Biology and Medicine 139, 422-427.

Alzueta C, Ortiz L, Rebole A, Rodriguez M, Centeno C \& Trevino J (2002) Effects of removal of mucilage and enzyme or sepiolite supplementation on the nutrient digestibility and metabolizable energy of a diet containing linseed in broiler chickens. Animal Feed Science and Technology 97, 169-181.

Anderson D, McCracken V, Aminov R, Simpson J, Mackie R, Verstegen M \& Gaskins H (1999) Gut microbiology and growth-promoting antibiotics in swine. Pig News and Information $20,115 \mathrm{~N}-122 \mathrm{~N}$.
Andoh A, Takaya H, Araki Y, Tsujikawa T, Fujiyama Y \& Bamba $T$ (2000) Medium- and long-chain fatty acids differentially modulate interleukin-8 secretion in human fetal intestinal epithelial cells. Journal of Nutrition 130, 2636-2640.

Aurousseau B, Thivend P \& Vermorel M (1984) Influence du remplacement d'une partie du suif d'un aliment par la tricaproqne ou de la tricapryline en assocation à de l'huile de coprah sur la croissance du jeune veau préruminant (Influence of replacement of part of the tallow in a food by tricaproqne or tricapryline in association with coconut oil on the growth of young preruminant calves). Annales de Zootechnie 33, 219-234.

Averette Gatlin L, Odle J, Soede J \& Hansen J (2002) Dietary medium- or long-chain triglycerides improve body condition of lean-genotype sows and increase suckling pig growth. Journal of Animal Science 80, 38-44.

Azain M (1993) Effects of adding medium-chain triglycerides to sow diets during late gestation and early lactation on litter performance. Journal of Animal Science 71, 3011-3019.

Beisson F, Ferté N, Bruley S, Voultoury R, Verger R \& Arondel V (2001) Oil-bodies as substrates for lipolytic enzymes. Biochimica et Biophysica Acta 1531, 47-58.

Bergner H \& Sommer A (1994) Einsatz von freien Fettsäuren in der Tierernährung (Use of free fatty acids in animal nutrition). Archives of Animal Nutrition 46, 217-236.

Boddie R \& Nickerson S (1992) Evaluation of postmilking teat germicides containing Lauricidin $\AA$, saturated fatty acids and lactic acid. Journal of Dairy Science 75, 1725-1750.

Brouns F \& Van der Vusse G (1998) Utilization of lipids during exercise in human subjects: metabolic and dietary constraints. British Journal of Nutrition 79, 117-128.

Canas-Rodriguez A \& Smith W (1966) The identification of the antimicrobial factors of the stomach contents of sucking rabbits. Biochemical Journal 100, 79-82.

Cera K, Mahan D \& Reinhart G (1989a) Apparent fat digestibilities and performances responses of postweaning swine fed diets supplemented with coconut oil, corn oil or tallow. Journal of Animal Science 67, 2040-2047.

Cera K, Mahan D \& Reinhart G (1989b) Postweaning swine performances and serum profile responses to supplemental medium-chain free fatty acids and tallow. Journal of Animal Science 67, 2048-2055.

Cerchiari E (2000) Active matrix technology making more of acids. Pig Progress 16, 34-35.

Cherrington C, Hinton M, Mead G \& Chopra I (1991) Organic acids: chemistry, antibacterial activity and practical applications. Advances in Microbial Physiology 32, 87-108.

Chiang S, Pettigrew J, Clarke S \& Cornelius S (1990a) Digestion and absorption of fish oil by neonatal piglets. Journal of Nutrition 118, 1741-1743.

Chiang S, Pettigrew J, Clarke S \& Cornelius S (1990b) Limits of medium-chain and long-chain triacylglycerol utilization by neonatal piglets. Journal of Animal Science 68, 1632-1638.

Clark S, Brause B \& Holt P (1969) Digestion and absorption of fat in the rat stomach. Gastroenterology 56, 214-222.

Coates M (1980) The gut microflora and growth. In Growth in Animals, pp. 175-180 [T Lawrence, editor]. Boston, MA: Butterworths.

Committee on Food Chemicals Codex (1981) Food Chemicals Codex, [Institute of Medicine of Washington DC, Editor] Oxford, UK: National Academy Press.

Cowan M (1999) Plant products as antimicrobial agents. Clinical Microbiology Reviews 12, 564-582.

Crozier G, Bois-Joyeux B, Chanez M, Girard J \& Peret J (1987) Metabolic effects induced by long-term feeding of mediumchain triglycerides in the rat. Metabolism 36, 807-814.

Czernichow B, Galluser M, Cui S, Gosse F \& Raul F (1996) Comparison of enteral or parenteral administration of medium 
chain triglycerides on intestinal mucosa in adult rats. Nutrition Research 16, 797-804.

Decuypere J, Dierick N, Vervaeke I \& Henderickx H (1991) Influence of Virginiamycin on the digestive physiology in precaecal re-entrant cannulated piglets. Archives of Animal Nutrition 41, 373-393.

Decuypere J \& Meeus J (1995) Aspects nouveaux de la mode d'action des acides dans l'alimentation porcine (New aspects of the mode of action of acids in pig feed). Journée d'Étude Kemin Europa, Rennes (France), 27 Juin, 1995. Herentals, Belgium: Kemin Europa.

De Rodas B \& Maxwell C (1990) The effect of fat source and medium-chain triglyceride level on performance of the earlyweaning pig. In Animal Science Research Report, pp. 278-287. Stillwater, OK: Oklahoma Agricultural Experimental Station.

Dierick N \& Decuypere J (2002) Endogenous lipolysis in feedstuffs and compound feeds for pigs: effects of storage time and conditions and exogenous lipase and/or emulsifier addition. Animal Feed Science and Technology 102, 53-70.

Dierick N, Decuypere J \& Degeyter I (2003) The combined use of whole Cuphea seeds containing medium chain fatty acids and an exogenous lipase in piglet nutrition. Archives of Animal Nutrition 57, 49-63.

Dierick N, Decuypere J, Molly K, Van Beek E \& Vanderbeke E (2002a)The combined use of triacylglycerols (TAGs) containing medium chain fatty acids (MCFAs) and exogenous lipolytic enzymes as an alternative for nutritional antibiotics in piglet nutrition. I. In vitro screening of the release of MCFAs from selected fat sources by selected exogenous lipolytic enzymes in simulated pig gastric conditions and their effects on the gut flora of piglets. Livestock Production Science 75, 129-142.

Dierick N, Decuypere J, Molly K, Van Beek E \& Vanderbeke E (2002b) The combined use of triacylglycerols (TAGs) containing medium chain fatty acids (MCFAs) and exogenous lipolytic enzymes as an alternative for nutritional antibiotics in piglet nutrition. II. In vivo release of MCFAs in gastric cannulated and slaughtered piglets by endogenous and exogenous lipases; effects on the luminal gut flora and growth performance. Livestock Production Science 76, 1-16.

Dierick N, Decuypere J, Vervaeke I \& Henderickx H (1981) Resorption of amino acids from an isolated loop of the pig's small intestine in vivo: influence of a nutritional dose of Virginiamycin. In Recent Advances in Germfree Research, pp. 369-372 [S Sasaki, A Ozawa and K Hashimoto, editors]. Tokyo, Japan: Tokai University Press.

Dierick N, Vervaeke I, Decuypere J \& Henderickx H (1986a) Influence of the gut flora and of some growth-promoting feed additives in nitrogen metabolism in pigs. I. Studies in vitro. Livestock Production Science 14, 161-176.

Dierick N, Vervaeke I, Decuypere J \& Henderickx H (1986b) Influence of the gut flora of some growth-promoting feed additives in nitrogen metabolism in pigs. II. Studies in vivo. Livestock Production Science 14, 177-193.

Dove C (1993) The effect of adding copper and various fat sources to the diets of weanling swine on growth performance and serum fatty acid profiles. Journal of Animal Science 71, 2187-2192.

Edwards-Webb J \& Thompson S (1977) Studies on lipid digestion in the preruminant calf. 2 . A comparison of the lipolysis of milk fat by salivary and pancreatic lipases in vitro. British Journal of Nutrition 37, 431-440.

Fakler T, Sohn K \& Maxwell C (1992) Effect of protein and fat source on performance in early weaned pigs. In Oklahoma Agricultural Experimental Station Research Report, pp. 366-372. Stillwater, OK: Oklahoma Agricultural Experimental Station.

Fay J \& Farias R (1975) The inhibitory action of fatty acids on the growth of Escherichia coli. Journal of General Microbiology 91, 233-240.
Ferguson A (1974) Intestinal immunity. The role of intraepithelial lymphocytes. PhD thesis, University of Glasgow, UK.

Freese E, Sheu C \& Galliers E (1973) Function of lipophylic acids as antimicrobial food additives. Nature 241, 321-325.

Galluser M, Czernichow H, Gossé F, Guérold B, Kachelhofer J, Doffoel M \& Raul F (1993) Comparison of different lipid substrates on intestinal adaptation in the rat. Gut 34, 1069-1074.

Gaskins H, Collier C \& Anderson D (2002) Antibiotics as growth promotants: mode of action. Animal Biotechnology 13, 29-42.

Glaps J (1970) Cited by Bergner H \& Sommer A (1994) Einsatz von freien Fettsäuren in der Tierenährung (Use of free fatty acids in animal nutrition). Archives of Animal Nutrition 46, 217-236.

Graham S (1989) Cuphea: a new plant source of medium-chain fatty acids. Critical Reviews in Food Science and Nutrition 28, 139-173.

Greenberger N, Franks J \& Isselbacher K (1965) Metabolism of 1$\mathrm{C}^{14}$ octanoic and $1-\mathrm{C}^{14}$ palmitic acid by rat intestinal slices. Proceedings of the Society for Experimental and Biological Medicine 120, 468-471.

Guillot E, Vaugelade P, Lemarchal P \& Rérat A (1993) Intestinal absorption and liver uptake of medium-chain fatty acids in nonanaesthetized pigs. British Journal of Nutrition 69, 431-442.

Guthery B (1993) Disinfecting product and process. US patent no. $5 \cdot 234 \cdot 703$.

Hamosh M (1997) Introduction: should infant formulas be supplemented with bioactive components and conditionally essential nutrients present in human milk? Journal of Nutrition 127, 971S-974S.

Hamosh M, Bitman J, Liao T, Mehta N, Buczek R, Wood D, Grylack L \& Hamosh P (1989) Gastric lipolysis and fat absorption in preterm infants: effect of MCT and LCT containing formulas. Pediatrics 83, 86-92.

Hamosh M, Scanlon J, Ganot D, Likel M, Scanlon K \& Hamosh P (1981) Fat digestion in the newborn. Characterisation of lipase in gastric aspirates of premature and term infants. Journal of Clinical Investigation 67, 838-846.

Hendrich S, Lii C, Myers R \& Dupont J (1993) Effect of feeding Cuphea oil to three generations of $\mathrm{CBA} / 2$ and $\mathrm{C} 57 \mathrm{~B} 1 / 6$ mice. Journal of AOACS International 70, 797-802.

Höller H (1970) Untersuchungen über Sekret und Sekretion der Cardiadrüsen Zone im Magen des Schweines (Investigations on the secretion of the cardiac zone in the stomach of the pig). Zentralblatt für Veterinarmedizin A17, 685-711.

Hsiao C \& Siebert K (1999) Modeling the inhibitory effects of organic acids on bacteria. International Journal of Food Microbiology 47, 189-201.

Hunt J \& Knox M (1986) A relation between the chain length of fatty acids and the slowing of gastric emptying. Journal of Physiology 194, 327-336.

Hurst G (1978) Crop impactions in bobwhite quail in Louisiana. Journal of Wildlife Diseases 124, 355.

Iba T, Yagi Y, Kidokoro A, Ohno Y, Kaneshiro Y \& Akiyama T (1998) Total parenteral nutrition supplemented with mediumchain triacylglycerols prevents atrophy of the intestinal mucosa in septic rats. Nutrition 14, 667-671.

Ingle D, Driedger A, Traul K \& Nakhasi D (1999) Dietary energy value of medium-chain triglycerides. Journal of Food Science 64, 960-963.

Isaacs C (2001) The antimicrobial function of milk lipids. Advances in Nutritional Research 10, 271-285.

Isaacs C, Kashyap S, Heird W \& Thormar H (1990) Antiviral and antibacterial lipids in human milk and infant formula feeds. Archives of Disease in Childhood 65, 861-864.

Isaacs C, Litov R, Marie P \& Thormar H (1992) Addition of lipases to infant formulas produces antiviral and antibacterial activity. Journal of Nutritional Biochemistry 3, 304-308. 
Isaacs C, Litov R \& Thromar H (1995) Antimicrobial activity of lipids added to human milk, infant formula and bovine milk. Journal of Nutritional Biochemistry 6, 362-366.

Jacobs M (1940) Some aspects of cell permeability to weak electrolytes. Cold Spring Harbor Symposium on Quantitative Biology 8, 30-39.

Jean K-B \& Chiang S-H (1999) Increased survival of neonatal pigs by supplementing medium-chain triglycerides in lategestating sow diets. Animal Feed Science and Technology 76, 241-250.

Jenkins A \& Thompson R (1993) Does the fatty acid profile of dietary fat influence its trophic effect on the small intestinal mucosa. Gut 34, 358-364.

Jensen B (1998) The impact of feed additives on the microbial ecology of the gut in young pigs. Journal of Animal and Feed Science 7, 45-64.

Jensen B, Højberg O, Mikkelsen L, Hedemann M \& Canibe N (2003) Enhancing intestinal function to treat and prevent disease. In Proceedings of the 9th International Symposium on Digestive Physiology in Pigs, vol. 1, pp. 103-119 [R Ball, editor]. Edmonton, Canada: University of Alberta.

Jensen M, Jensen S \& Jakobsen K (1997) Development of digestive enzymes in pigs with emphasis on lipolytic activity in the stomach and pancreas. Journal of Animal Science 75, 437-445.

Jin C, Kim J, Han I, Jung H \& Kwon C (1998) Effects of various fat sources and lecithin on the growth performance and nutrient utilization in pigs weaned at 21 days of age. Asian Australian Journal of Animal Science 11, 176-184.

Joerger R (2003) Alternatives to antibiotics: bacteriocins, antimicrobial peptides and bacteriophages. Poultry Science 82, 640-647.

Kabara J (1984) Medium-chain fatty acids and esters as antimicrobial agents. In Cosmetic and Drug Preservation, Principles and Practice, pp. 275-304 [J Kabara, editor]. New York: Marcel Dekker.

Kabara J, Swieczkowski D, Conley A \& Truant J (1972) Fatty acids and derivates as antimicrobial agents. Antimicrobial Agents and Chemotherapy 2, 23-28.

Kanai K \& Kondo E (1979) Antibacterial and cytotoxic aspects of long-chain fatty acids as cell superface events: selected topics. Japanese Journal of Medical Science and Biology 32, 135-174.

Kimura Y, Hosoda Y, Yamaguchi M, Nagano H, Shima M, Adachi S \& Matsuno R (2001) Effects of medium-chain fatty acids on intracellular calcium levels and the cytoskeleon in human intestinal (Caco-2) cell monolayers. Bioscience Biotechnology and Biochemistry 65, 743-751.

Kinderlerer J, Matthias H \& Finner P (1996) Effect of mediumchain fatty acids in mould ripened cheese on the growth of Listeria monocytogenes. Journal of Dairy Research 63, 593-606.

Knarreborg A, Simon M, Engberg R, Jensen B \& Tannock G (2002) Effects of dietary fat source and subtherapeutic levels of antibiotic on the bacterial community in the ileum of broiler chickens at various ages. Applied and Environmental Microbiology 68, 5918-5924.

Léon A, Schmidt I, Strullu F, Fillaut M, Gautier J, Hulin J, Lebreton Y, Herpin P \& Dividich J (1998) Effects of substitution of medium- for long-chain triglycerides in colostrum on the energy metabolism of the newborn pig in relation to environmental temperature. Journées de la Recherche Porcine en France 30, 275-290.

Leser D, Amenuvor J, Jensen T, Lindecrona R, Boye M \& Møller K (2002) Culture-independent analysis of gut bacteria: the pig gastrointestinal tract microbiota revisited. Applied and Environmental Microbiology 68, 673-690.
Li B, Van Kessel A, Caine W, Huang S \& Kirkwood R (2001) Small intestinal morphology and bacterial populations in ileal digesta and feces of newly weaned pigs receiving a high dietary level of zinc oxide. Canadian Journal of Animal Science 81, 511-516.

Li FC, Hang YN \& Shen TF (2001) Development of lipase in nursing piglets. Proceedings of the National Science Council Of the Republic of China 25B, 12-16.

Lin C, Chiang S \& Fee H (1995) Causes of reduced survival of neonatal pigs by medium-chain triglycerides: blood metabolite and behavioral activity approaches. Journal of Animal Science 73, 2019-2025.

Lindmark T, Kimura Y \& Artursson P (1998) Absorption enhancement through intracellular regulation of tight junction permeability by medium chain fatty acids in Caco-2 cells. Journal of Pharmacology and Experimental Therapy 284, 362-369.

Lindmark T, Nikkila T \& Artursson P (1995) Mechanisms of absorption enhancement by medium chain fatty acids in intestinal epithelial Caco-2 cell monolayers. Journal of Pharmacology and Experimental Therapy 275, 958-964.

Lis-Balchin M (2003) Feed additives as alternatives to antibiotic growth promoters: botanicals. In Proceedings of the 9th International Symposium on Digestive Physiology in Pigs, vol. 1, pp. 333-352 [R Ball, editor]. Edmonton, Canada: University of Alberta.

Mabayo R, Furuse M, Kita K \& Okumura J (1993) Improvement of dietary protein utilisation in chicks by medium chain triglyceride. British Poultry Science 34, 121-130.

Mabayo R, Furuse M, Murai A \& Okumura J (1994) Interactions between medium-chain and long-chain triacylglycerols in lipid and energy metabolism in growing chicks. Lipids 29, 139-144.

Mabayo R, Furuse M, Yang S \& Okumura J (1992) Medium-chain triacylglycerols enhance release of cholecystokinin in chicks. Journal of Nutrition 122, 1702-1705.

Mahan D (1991) Efficacy of initial postweaning diet and supplemental coconut oil or soybean oil for weanling swine. Journal of Animal Science 69, 1397-1402.

Meeus J (1994) De antimicrobiële activiteit van organische zuren en $\mathrm{pH}$ op de darmflora bij het varken (The antimicrobial activity of organic acids and $\mathrm{pH}$ on the gut flora of the pig). Thesis Landbouwkundig Ir., Faculty of Agricultural and Applied Biological Sciences, Ghent University, Belgium.

Molimard P, Le Quéré J \& Spinner H (1997) Les lipides et la flaveur des produits laitiers (Lipids and flavours of dairy products). Oléagineux, Corps Gras, Lipides 4, 301-312.

Moreau H, Gargouri Y, Lecat D, Junien J-L \& Verger R (1988) Screening of preduodenal lipases in several mammals. Biochimica et Biophysica Acta 959, 247-252.

Mroz Z (2003) Organic acids of various origin and physico-chemical forms as potential alternatives to antibiotic growth promoters for pigs. In Proceedings of the 9th International Symposium on Digestive Physiology in Pigs, vol. 1, pp. 267-293 [R Ball, editor]. Edmonton, Canada: University of Alberta.

Newcomb M, Harmon D, Nellsen J, Thulin A \& Allee G (1991) Effect of energy source fed to sows during late gestation on neonatal blood metabolite homeostasis, energy stores and composition. Journal of Animal Science 69, 230-236.

Newport M \& Howarth G (1985) Contribution of gastric lipolysis to the digestion of fat in the neonatal pig. In Proceedings of the 3rd International Seminar on Digestive Physiology in the Pig, Copenhagen, Denmark, 16-18 May 1985, pp. 143-145 [A Just, $\mathrm{H}$ Jorgensen and JA Fernández, editors]. Copenhagen, Denmark: National Institute of Animal Science.

Newport M, Storry J \& Tuckley B (1979) Artificial rearing of pigs. 7. Medium chain triglycerides as a dietary source of energy and their effect on live-weight gain, feed:gain ratio, carcass compostion and blood lipids. British Journal of Nutrition 41, 85-93. 
O'Connor J, Perry H \& Harwood J (1992) A comparison of lipase activity in various cereal grains. Journal of Cereal Science 16, 15.

Odle J (1997) New insights into the utilization of medium-chain triglycerides by the neonate: observations from a piglet model. Journal of Nutrition 127, 1061-1067.

Odle J (1999) Medium-chain triglycerides: A unique energy source for neonatal pigs. Pig News and Information 20, 25N-32N.

Odle J, Bevenenga N \& Crenshaw $\mathrm{T}$ (1991) Utilization of medium-chain triglycerides by neonatal piglets: chain length of even- and odd-carbon fatty acids and apparent digestion/absorption and hepatic metabolism. Journal of Nutrition 121, 605-614.

Oh D-H \& Marshall D (1993) Antimicrobial activity of ethanol, glycerol monolaurate or lactic acid against Listeria monocytogenes. International Journal of Food Microbiology 20, 239-246.

Ostling C \& Lindgren S (1993) Inhibition of enterobacteria and Listeria growth by lactic, acetic and formic acid. Journal of Applied Bacteriology 75, 18-24.

Ostrowski H, Rys R \& Morstin E (1972) cited by Bergner H \& Sommer A (1994) Einsatz von freien Fettsäuren in der Tierernährung (Use of free fatty acids in animal nutrition). Archives of Animal Nutrition 46, 217-236.

Pandey A, Benjamin S, Soccol C, Nigam P, Krieger N \& Soccol V (1999) The realm of microbial lipases in biotechnology. Biotechnology and Applied Biochemistry 29, 119-131.

Partanen K \& Mroz Z (1999) Organic acids for performance enhancement in pig diets. Nutrition Research Reviews 12, $117-145$.

Perez-Castorena A \& Maldonado E (2003) Triterpenes and flavonoid glycosides from Cuphea wrightii. Biochemical Systematics and Ecology 31, 331-334.

Petersen D (1999) Lipase activity and lipid metabolism during oat malting. Cereal Chemistry 76, 159-163.

Petrone G, Conte M, Longhi C, Di Santo S, Superti F, Ammendolia M, Valenti P \& Seganti L (1998) Natural milk fatty acids affect survival and invasiveness of Listeria monocytogenes. Letters in Applied Bacteriology 27, 352-368.

Petschow B, Batema R, Talbott R \& Ford L (1998) Impact of medium-chain monoglycerides on intestinal colonisation by Vibrio cholerae or enterotoxigenic Escherichia coli. Journal of Medical Microbiology 47, 383-389.

Petterson DS, Harris DJ, Rayner CJ, Blakeney AB \& Choct M (1999) Methods for the analysis of premium livestock grains. Australian Journal of Agricultural Research 50, 775-787.

Puupponen-Pimiä R, Aura A, Oksman-Caldentey K, Myllärinen P, Saarela M, Mattila-Sandholm T \& Poutanen K (2002) Development of functional ingredients for gut health. Trends in Food Science and Technology 13, 3-11.

Ricke S (2003) Perspectives on the use of organic acids and short chain fatty acids as antimicrobials. Poultry Science 82, 632-639.

Røsjø C, Nordrum S, Olli J, Krogdahl A, Ruyter B \& Holm H (2000) Lipid metabolism in Atlantic salmon (Salmo salar) fed medium-chain triglycerides. Aquaculture 190, 65-76.

Roth F \& Kirchgessner M (1998) Organic acids as feed additives for young pigs: nutritional and gastrointestinal effects. Journal of Animal and Feed Sciences 7, 25-35.

Rys R, Urbanczyk J \& Gawlik J (1969/70) Anwendung synthethiser Fettsäuren in der Schweinefütterung (Application of synthesised fatty acids in pig diets). Jahrbuch für Tierernährung und Fütterung 7, 224-231.

Salatino A, Salatino M, Dos Santos D \& Patricio M (2000) Distribution and evolution of secondary metabolites in Eriocaulaceae, Lythraceae and Velloziaceae from 'campos rupestres'. Genetics and Molecular Biology 23, 931-940.

Samson F, Dahl N \& Dahl D (1956) A study on the narcotic action of the short chain fatty acids. Clinical Investigation 35, 1291-1298.
Sheu C, Salomon D, Simmons J, Sreevalsan T \& Freese E (1975) Inhibitory effects of lipophilic acids and related compounds on bacteria and mammalian cells. Antimicrobial Agents and Chemotherapy 7, 349-363.

Shima M, Kimura Y, Adachi S \& Matsuno R (1998) The relationship between transport-enhancement effects and cell viability by capric acid sodium salt, monocaprin and dicaprin. Bioscience Biotechnology and Biochemistry 62, 83-86.

Shima M, Kimura Y, Adachi S \& Matsuno R (1999) Recovery of Caco-2 cell monolayers to normal from the transport-enhanced state induced by capric acid sodium salt and its monoacylglycerol. Bioscience Biotechnology and Biochemistry 63, 680-687.

Shurson G, Ku P, Waxler G, Yokoyama M \& Miller E (1990) Physiological relationships between microbiological status and dietary copper levels in the pig. Journal of Animal Science $\mathbf{6 8}$, 1061-1071

Simpson M, McCracken V, White B, Gaskins H \& Mackie R (1999) Application of denaturant gradient gel electrophoresis for the analysis of the porcine gastrointestinal microbiota. Journal of Microbiological Methods 36, 167-179.

Smith H (1966) The antimicrobial activity of the stomach contents of suckling rabbits. Journal of Pathological Bacteriology 91, 1-9.

Smith S (1980) Mechanism of chain length determination in biosynthesis of milk fatty acids. Journal of Dairy Science $\mathbf{6 3}$, 337-352.

Snel J, Harmsen H, Van der Wielen P \& Willimas B (2002) Dietary strategies to influence the gastro-intestinal microflora of young animals and its potential to improve intestinal health. In Nutrition and Health of the Gastrointestinal Tract, pp. 37-69 [M Blok, H Vahl, L de Lange, A Van de braak, L Hemke and M Hessing, editors]. Wageningen, The Netherlands: Wageningen Academic Publishers.

Sprong R, Hulstein M \& Van Der Meer R (2002) Bovine milk fat components inhibit food-borne pathogens. International Dairy Journal 12, 209-215.

Stahly T (1983) Method for improving the metabolic stability and survival of neonatal pigs. US patent no. 4.423.072.

Stubbs J \& Slabas A (1982) Ultrastructural and biochemical characterization of the epidermal hairs of the seeds of Cuphea procumbens. Planta 155, 392-399.

Symersky T, Vu M, Frolich M, Biemond I \& Masclee A (2002) The effect of equicaloric medium-chain and long-chain triglycerides on pancreas secretion. Clinical Physiology and Functional Imaging 22, 307-311.

Takada R, Shidara O, Saitoh M \& Mori T (1992) Effects of feeding medium chain triglycerides on growth performance, digestibility, backfat thickness and fatty acid composition in finishing pigs. Japanese Journal of Swine Science 29, 32-40.

Takase S \& Goda T (1990) Effects of medium-chain triglycerides on brush border membrane-bound enzyme activity in rat small intestine. Journal of Nutrition 120, 969-976.

Thomke S \& Elwinger K (1998a) Growth promotants in feeding pigs and poultry. I. Growth and feed efficiency responses to antibiotic growth promotants. Annales de Zootechnie 47, 85-97.

Thomke S \& Elwinger K (1998b) Growth promotants in feeding pigs and poultry. II. Mode of action of antibiotic growth promotants. Annales de Zootechnie 47, 153-167.

Thomke S \& Elwinger K (1998c) Growth promotants in feeding pigs and poultry. III. Alternatives to antibiotic growth promotants. Annales de Zootechnie 47, 245-271.

Timmermann F (1993) Medium chain triglycerides, the unconventional oil. International Food Ingredients 3, 11-18.

Traul K, Driedger A, Ingle D \& Nakhasi D (2000) Review of toxicological properties of medium-chain triglycerides. Food and Chemical Toxicology 38, 79-98. 
Tsuchido T, Hiraoka T, Takano M \& Shibasaki I (1985) Involvement of autolysin in cellular lysis of Bacillus subtilis induced by short- and medium-chain fatty acids. Journal of Bacteriology 162, 42-46.

Van Den Bossche A, Van Nevel C, Herman L, Decuypere J, De Smet S, Dierick N \& Heyndrickx M (2001) PCR-TGGE: a method for fingerprinting the microbial flora in the small intestine of pigs. Mededelingen Faculteit Landbouwkundige Wetenschappen, Universiteit Gent 66, 359-363.

Van Hoogdalem E, De Boer A \& Breimer D (1989) Intestinal drug enhancement: an overview. Pharmacology and Therapeutics Journal 44, 407-433.

Van Leeuwen P, Jansman A, Esteve-Garcia E \& Van Dijk J (2001) Effects of Virginiamycin on histology of the small intestinal mucosa in piglets. In Digestive Physiology of Pigs, pp. 274-276 [JE Lindberg and B Ogle, editors]. Wallingford, Oxon: CABI Publishing.

Vega-Lopez M, Arenas-Contreras G, Bailey M, Gonzalez-Pozos S, Stokes C, Ortega M \& Mondragon-Flores R (2001) Development of intraepithelial cells in the porcine small intestine. Developmental Immunology 8, 147-158.

Velasquez O, Seto R \& Rombeau J (1996) The scientific rationale and clinical application of short-chain fatty acids and mediumchain fatty acids. Proceedings of the Nutrition Society 55, 49-78.

Verstegen M \& Schaafsma G (1999) Some developments for antibiotics as growth promotor. In Nutrition and
Gastrointestinal Physiology - Today and Tomorrow, pp. 65-73 [A Jansman and $\mathrm{J}$ Huisman, editors]. Wageningen, The Netherlands: TNO.

Vervaeke I, Decuypere J, Dierick N \& Henderickx H (1979) Quantitative in vitro evaluation of the energy metabolism influenced by Virginiamycin and Spiramycin used as growth promoters in pig nutrition. Journal of Animal Science 49, 846-856.

Visek W (1978) The mode of growth promotion by antibiotics. Journal of Animal Science 46, 1447-1469.

Wächtershäuser A \& Stein J (2000) Rationale for the luminal provision of butyrate in intestinal diseases. European Journal of Nutrition 39, 164-171.

Wang L \& Johnson E (1992) Inhibition of Listeria monocytogenes by fatty acids and monoglycerides. Applied and Environmental Microbiology 58, 624-629.

Wargovich M, Eng V \& Newmark H (1984) Calcium inhibits the damaging and compensatory proliferative effects of fatty acids on mouse colon epithelium. Cancer Letters 23, 253-258.

Wiseman J \& Agunbiade J (1998) The influence of changes in dietary fat and oils on fatty acid profiles of carcass fat in finishing pigs. Livestock Production Science 54, 217-227.

Woolford M (1975) Microbiological screening of the straight chain fatty acids (C1-C12) as potential silage additives. Journal of the Science of Food and Agriculture 26, 219-228. 
https://doi.org/10.1079/NRR200369 Published online by Cambridge University Press 